\title{
PLIOCENE BRACHIOPODS FROM RHODES ISLAND (CAPE VAGIA SECTION)
}

\author{
Koskeridou E. ${ }^{1}$ \\ ${ }^{1}$ National and Kapodistrian University of Athens, Faculty of Geology and Geoenvironment, \\ Department of Hist. Geology-Paleontology, ekosker@geol.uoa.gr
}

\begin{abstract}
Six brachiopod species (5 terebratulids and 1 craniid) from the upper Pliocene sandy and calcareous deposits of the Cape Vagia (Rhodes Island) are described: Gryphus sp., Terebratulina retusa, Megerlia truncata, Megerlia truncata var. monstruosa, Argyrotheca cordata, Megathiris detruncata and Novocrania anomala. This is the first record of Megerlia truncata var. monstruosa from the Pliocene of Greece and of Megerlia truncata from the Pliocene of Rhodes. Megathiris detruncata, Terebratulina retusa and Argyrotheca cordata are described for the first time from the Pliocene of Rhodes. This brachiopod association displays close affinity with those from the Mediterranean province, where assemblages of similar composition are associated with shallow-water, high energy environments. However, the association of Gryphus sp., Terebratulina retusa and Novocrania anomala corresponds to deeper water moderate environments.
\end{abstract}

Key words: Pliocene, Mediterranean, Brachiopods, Rhodes, Greece.

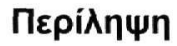

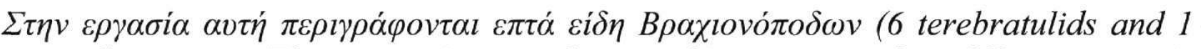

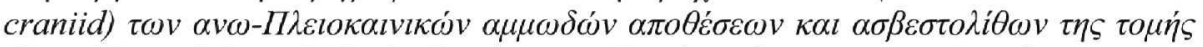

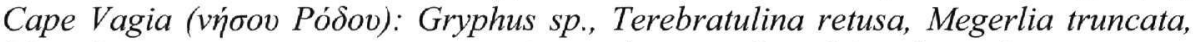
Megerlia truncata var. monstruosa, Argyrotheca cordata, Megathiris detruncata kol Novocrania anomala.

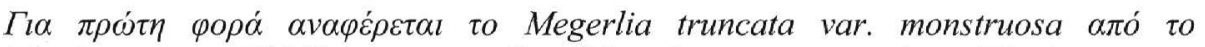

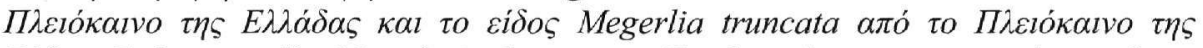

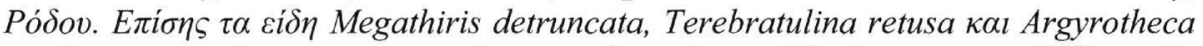

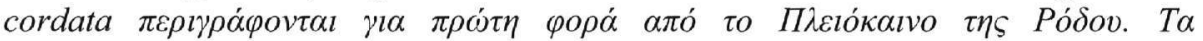

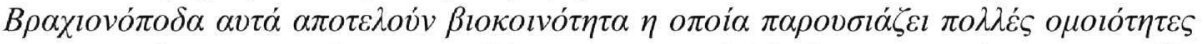

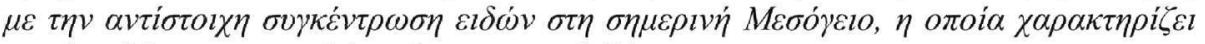

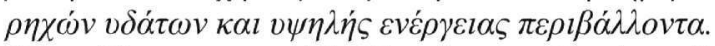

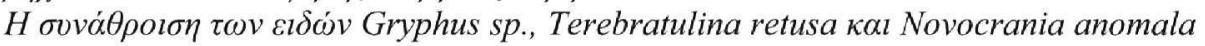

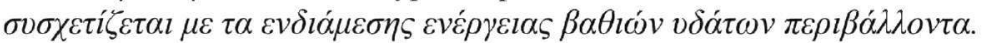

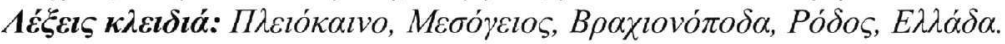




\section{Introduction}

Pliocene brachiopods of Greece have merely been mentioned or listed by a number of authors in studies dealing with mollusc faunas (Symeonides 1966, Dermitzakis 1969, Mutti et al. 1970b, Georgiades-Dikeoulia 1974, Spanopoulou 1997, Steinthorsdottir et al. 2006).

Pliocene brachiopods are also described from other Mediterranean regions such as Italy and Spain (see Bitner and Martinell 2001).

The Cape Vagia section in Rhodes Island is an extremely interesting area for the study of Pliocene brachiopods and their environments from shallow to deeper water, yielding a micromorph association. This section is located in a southfacing basin on the eastern coast of Rhodes, in the bay south of Cape Vagia (Fig.1).

In the present work the studied fauna comes from the lower part of the Cape Vagia section that belongs to the upper Pliocene Kolymbia limestone Member.

Even though the existence of brachiopods in the Kolymbia limestone was mentioned by Moissette and Spjeldnaes (1995), Spanopoulou (1997) and Steinthorsdottir et al. (2006), this is the first time that a micromorph fauna is described from the Pliocene deposits of Greece. Megathiris detruncata, Argyrotheca cordata, Megerlia truncata, Megerlia truncata var. monstruosa and Terebratulina retusa are described for the first time from the Pliocene of Rhodes and Megerlia truncata var. monstruosa for the first time from the Pliocene of Greece. The taxonomic position of the specimens described by Steinthorsdottir et al. (2006) as Gryphus vitreus has been revised.

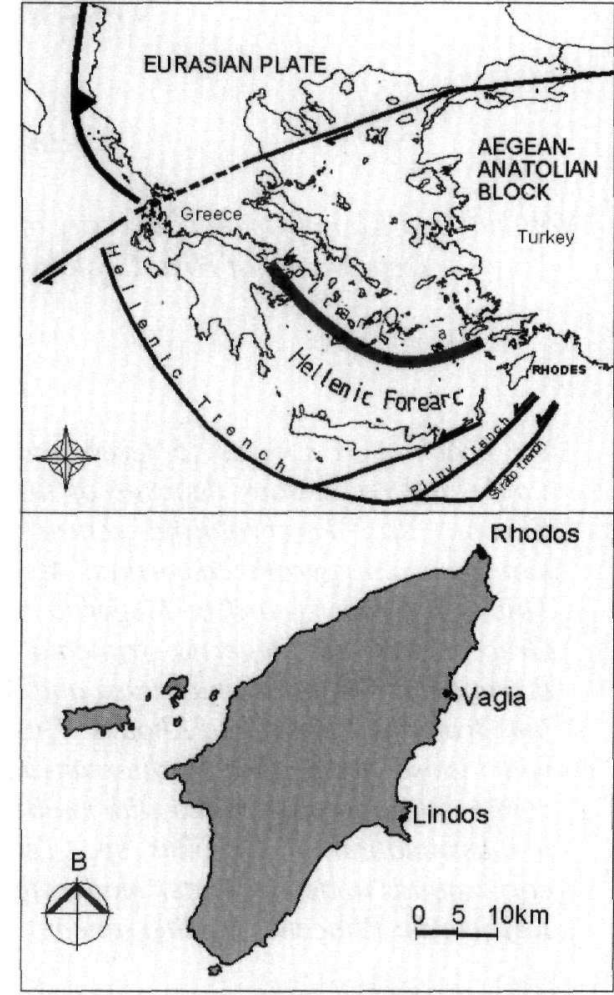

Figure 1 - Position of Rhodes in the Aegean Arc and schematic map of indicating the location of the Cape Vagia area

In this study the collected brachiopod assemblages are analyzed and a paleoenvironmental interpretation is proposed, based on the micromorph fauna through the comparison with recent associations.

\section{Geological setting}

The Late Pliocene and Pleistocene marine succession of the island of Rhodes, overlies unconformably a metamorphosed Mesozoic limestone which formed a karstic landscape of considerable relief (Mutti et al. 1970a-b, Meulenkamp et al. 1972, Hanken et al. 1996). The infilling sequences are consequently of highly varying thickness.

In the Late Pliocene, a general tilting raised northeastern and lowered southwestern Rhodes. Normal faults separated the island into several tectonic blocks with differential vertical more or less independent and important movements (Mutti et al. 1970a-b, Pirazzoli et al. 1983, 1989, Hanken et al. 1996). These movements persisted during the Pleistocene and continue to the present day (Meulenkamp et al. 1972, Benda et al. 1977). 
Many authors proposed lithostratigraphic subdivisions of the Plio-Pleistocene deposits (Hedenborg 1837, Bukowski 1899, Mutti et al. 1970b, Meulenkamp et al. 1972, Hanken et al. 1996). Cornée et al. (2006) revised the tectonosedimentary organization of these deposits and defined a new formation (the Ladiko-Tsampika Fm) between the Rhodes Formation (now including three Members: Kritika, Kolymbia, and Lindos Bay clay) and the Lindos Acropolis Formation. The Pliocene-Pleistocene boundary was positioned within the Lindos Bay clay (Keraudren 1970, Sissingh 1972, Benda et al. 1977, Løvlie et al. 1989, Hanken et al. 1996). Thomsen et al. (2001) assigned an Early Pleistocene age to the whole marine sequence. Cornée et al. (2006a-b) established that these three formations range from Late Pliocene (Kritika to base of the Lindos Bay clay) to Middle Pleistocene in age.

The Upper Pliocene Kolymbia limestone on which the present study focuses, is a bryozoan-mollusc-dominated limestone corresponding to a deepening upward sequence (Moissette and Spjeldnaes 1995, Spjeldnaes and Moissette 1997, Steinthorsdottir et al. 2006). It consists of a muddy limestone at the base, overlain by a homogeneous limestone intercalated with coarser layers (Fig.2).

\section{Materials and Methods}

For this study, a total number of 5 samples were collected from the Cape Vagia section (Fig. 2). They were taken from the coarser beds which are characterized by large concentrations of shells and rhodoliths. Bulk samples of 1-1.5 kg were collected throughout the section. Samples 1 and 4 were treated with a solution of Glaubert's salt and then sieved through four mesh sizes $(2,1,0.5,0.25 \mathrm{~mm})$. After drying, fossils were picked, and identified to species level whenever possible. Information about their modern ecological characteristics and distribution were used for a paleoenvironmental reconstruction.

Macro and microphotographs of brachiopods were taken with a Jeol JSM 5600. The studied material is housed in the laboratory of the Department of Historical Geology-Paleontology, Section of Geology and Geoenvironment, Athens University.

\subsection{Paleontology}

The qualitative analysis led to the identification of 7 taxa of Brachiopods: Gryphus sp., Terebratulina retusa (Linnaeus), Argyrotheca cordata (Risso), Megerlia truncata (Linnaeus), Megerlia truncata var. monstruosa, Megathiris detruncata (Gmelin) and Novocrania anomala (Müller). Novocrania anomala has been already mentioned by Steinthorsdottir et al. 2006. However Gryphus vitreus identified by these authors is revised herein. The other species are described for the first time from the Pliocene of Greece.

Sample 1 is characterized by the dominance of Ostrea lamellosa and the presence of Argyrotheca cordata, Megerlia truncata, and Megathiris detruncata. Sample 2 is characterized by the abundance of Gryphus sp., the presence of Megerlia truncata var. monstruosa, and transported pectinids and rhodoliths. Sample 3 is dominated by Ostrea lamellosa, Pecten jacobaeus, the occurrence of Gryphus sp. in great number and the presence of Terebratulina retusa. Sample 4 is dominated by Gryphus sp. and Terebratulina retusa and Novocrania anomala is also present. 
Sample 5 contains transported rhodoliths, small ostreids and pectinids, Anomia ephippium and rare Gryphus sp.

\title{
SYSTEMATIC PALAEONTOLOGY
}

A new supra-ordinal classification of the Brachiopoda (Williams et al. 1996) has been used here.

Since most investigated species are well known, only some more important and/or recent synonymies are given.

\author{
PHYLUM BRACHIOPODA Dumeril, 1806 \\ SUBPHYLUM RHYNCHONELLIFORMEA Williams et al., 1996 \\ CLASS RHYNCHONELLATA Williams et al., 1996 \\ ORDER TEREBRATULIDA Waagen, 1883 \\ SUBORDER TEREBRATULIDINA Waagen, 1883 \\ Superfamily TEREBRATULOIDEA Gray, 1840 \\ Family Terebratulidae Gray, 1840 \\ Subfamily Gryphinae Sahni, 1929 \\ Genus Gryphus Megerle von Mühlfeld, 1811
}

Gryphus sp.

(Plate 1, Figs 1-4)

Morphology. The shell is very large, thick, subpentagonal, strongly biconvex, smooth, with concentric growth lines and has a large foramen. The lateral commissure is curvier than this of Gryphus vitreus. The shell is thicker posteriorly and is best preserved at this area. The dimensions of the collected specimens reach about $5 \mathrm{~cm}$ in length and $4.5 \mathrm{~cm}$ in width. The large size, the shell outline and the type of foramen resemble those of the Pliocene species Gryphus sphenoideus that was described by Gaetani and Sacca $(1984,1985)$. The internal features are unknown and the limited material prevents detailed investigations and identification to the specific level.

The specimens from the Kolymbia limestone attributed by Steinthorsdottir et al. (2006) to Gryphus vitreus have been re-investigated. It has the characteristics of our specimens and not those of the typical Gryphus vitreus.

Occurrence. The genus Gryphus is recorded from the Pliocene and Pleistocene of Italy, (Gaetani and Sacca 1984, 1985), of the Pliocene of Spain (Bitner and Martinell 2001) and the Pliocene of north-western Africa (Bitner and Moissette 2003).

The species Gryphus yitreus lives in the present day Mediterranean Sea. It is a stenotopic species and is observed on bottoms with moderate to strong currents, low sedimentation, abundance of nutriments and stable temperature and salinity. It has been found on substrates with gravels or shells of the bathyal zone, usually with Terebratulina retusa and on the shelf to the bathyal zone with Novocrania anomala (Logan 1979). The species found in the Kolymbia limestone is associated with this fauna too.

\section{Superfamily CANCELLOTHYRIDOIDEA Thomson, 1926 \\ Family Cancellothyridae Thomson, 1926 \\ Subfamily Cancellothyridinae Thomson, 1926 \\ Genus Terebratulina d'Orbigny, 1847 \\ Terebratulina retusa (Linnaeus, 1758)}

(Plate 1, Figs 5-6)

1758 Anomia retusa, Linnaeus, p. 701, no.191.

1983 Terebratulina retusa (Linnaeus) -Logan, p. 172.

1994 Terebratulina retusa (Linnaeus) -Taddei-Ruggiero, p. 209, pl. 2, figs 1-3.

Morphology. Shell biconvex, subpentagonal, longer than wide, slightly auriculate at hinge line. Anterior commissure uniplicate. Externally the valves have numerous, rather coarse, radial ribs, 
with smooth rounded tubercules at the postero- lateral margins of both valves. Foramen large, mesothyrid with pedicle collar. The collected specimens reach about $1.1 \mathrm{~cm}$ in length and $0.8 \mathrm{~cm}$ in width.

Occurrence. Today, T. retusa has a wide geographical distribution. It lives in the eastern North Atlantic, eastern Greenland, off Iceland and Mediterranean (Alboran Sea to Greece). Its bathymetric range is from 15 to 450 meters in the Mediterranean (421 $\mathrm{m}$ in Greece), deeper in the Eastern Atlantic (15 to $1478 \mathrm{~m}$, off the coast of the British Isles). In the bathyal zone it lives with Gryphus vitreus (Logan 1979).

It appeared in the Eocene and has been reported from the Pliocene and Pleistocene of Italy, (Gaetani and Sacca 1984, 1985, Taddei-Ruggiero 1994). In Rhodes, it has been also described from the Pleistocene deposits (Spanopoulou 1997).

In the Kolymbia limestone it has been found in samples 3 and 4 and it is probably coming from deeper water.

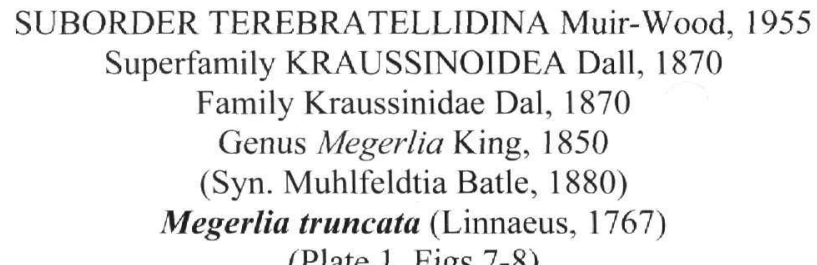

(Plate 1, Figs 7-8)

1767 Anomia truncata, Linné, p. 1152, no 229.

1927 Muhlfeldtia truncata (Linné) -Thomson, p. 226.

1979 Megerlia truncata (Linnaeus) -Logan, p. 68, tab. 9, figs 1-23.

1981 Megerlia truncata (Linné) -Cooper, p. 36, tab. 3, figs 5-11.

Morphology. Shell small, rounded, biconvex, wider than long. The anterior commissure is sulcate, brachial valve less convex than pedicle valve. Beak suberect, subtruncate, usually abraded. Foramen large, hypothyrid with pedicle collar. The collected specimens reach about $1.3 \mathrm{~cm}$ in length and $1.5 \mathrm{~cm}$ in width.

Occurrence. Today it is widely distributed in the Mediterranean and the North and East Atlantic, at depths of $15-200 \mathrm{~m}$. The individuals of $M$. truncata that live in shallow waters have cryptic habits, while the individuals that live in deeper waters exit from their hiding places and attached to small shells or gravels on the bottom of the sea (Logan 1979). In Greece it has been found at depths of 29 to $374 \mathrm{~m}$.

Megerlia truncata appeared in the Miocene. In Crete island it was described by GeorgiadesDikeoulia (1974) from the middle Miocene of St. Asomati, where there had been found the varieties serravallensis and sabata. Also, Symeonides (1966) mentions Muhlfeldtia truncata from the Pliocene of the hill of Vigla, of the village Pachia Amos and Dermitzakis (1969) Muhlfeldtia truncata from the Pliocene of St. Haralambos, Peristera and Coutsounari.

In Rhodes, it has been also described from the Pleistocene deposits (Spanopoulou 1997).

Family Kraussinidae Dal, 1870

Genus Pantellaria Dall, 1919

Megerlia truncata var. monstruosa (Scacchi, 1838)

(Plate 2, Figs 1-2)

1891 Muhlfeldtia monstruosa (Scacchi) -Fischer and Oehlert, p. 87, pl. 7, figs 12 a-c.

1927 Pantellaria monstruosa (Scacchi) - Thomson, p. 228, figs 70 a-c.

1979 Megerlia truncata (Linnaeus) - Logan, p. 68, pl. 9, figs 20-23.

1981 Pantellaria monstruosa (Scacchi) - Cooper, p. 17, pl. 3, figs 16-18. 
Morphology. Shell has almost smooth dorsal valve, where it has only distinct growth lines, often in clusters. Ventral valve ornamented with delicate radial ribs with nodulose crests. There are many different opinions about the taxonomic position of this taxa (see Logan 2004 and references herein). For the taxonomy I follow the opinion of Logan (1979) and Logan et al. (2004) which based on his observations and these of Davidson (1887) and Bitner (1990, 1993), regard monstruosa as a variety of $M$. truncata because the shape of the shell and the amphithyrid foramen is influenced by the angle of attachment to the substrate. The foramen is elongated to include the umbonal region of the dorsal valve. The collected specimens reach about $1 \mathrm{~cm}$ in length and $1.5 \mathrm{~cm}$ in width.

Occurrence. The Recent Megerlia truncata var. monstruosa, in the Mediterranean lives on rocky substrates at depths of 36 to $553 \mathrm{~m}$ (Cooper 1981, Logan 1979). In the eastern Atlantic it has been found at depths of 400-2780 m.

Superfamily MEGATHYRIDOIDEA Dall, 1870

Family Megathyrididae Dall, 1870

Genus Megathiris d'Orbigny, 1847

Megathiris detruncata (Gmelin, 1790)

(Plate 2, Figs 3-4)

1790 Anomia detruncata Gmelin, p. 3347.

1979 Megathiris detruncata (Gmelin) -Logan, p.55-59, text-figs 15, 16, pl. 6, figs 1-13.

1985 Megathiris detruncata (Gmelin) -Gaetani and Sacca, p. 17, 18, pl. 9, figs 10-12, pl. 6, figs $1-7$.

1994 Megathiris detruncata (Gmelin) -Taddei Ruggiero, p. 208, pl. 3, figs 6-9.

2003 Megathiris detruncata (Gmelin) -Bitner and Moissette, p. 473, fig. 6 (G,H).

Morphology. It is a micromorphic species with a biconvex shell, oval in outline, wide, straight hinge line, large triangular foramen and 10-14 broad ribs. The collected specimens are about $5 \mathrm{~mm}$ in length and $6 \mathrm{~mm}$ in width.

Occurrence. The Recent $M$. detruncata lives in the Mediterranean at depths of 20 to $160 \mathrm{~m}$ (Logan 1979). It also lives in the Lusitanian and Mauritanian regions of the Atlantic Ocean and in the Caribbean Sea (Logan 1983, 1988, 1993, Cooper 1977).

It is very common in the Miocene of the Paratethys (Bitner 1990) and the Pliocene of Italy (Gaetani and Sacca 1985, Taddei Ruggiero 1994) and it was described from the Pliocene of North Africa (Bitner and Moissette 2003). In Rhodes, it has been also mentioned from the Pliocene and described from the Pleistocene deposits by Spanopoulou (1997).

Family Megathyrididae Dall, 1870

Genus Argyrotheca Dall, 1900

(Syn. Cistella Gray, 1853)

Argyrotheca cordata (Risso, 1826)

(Plate 1, Figs 5-6)

1979 Argyrotheca cordata (Risso) -Logan, p.96, pl. 5, figs 1-12.

1994 Argyrotheca cordata (Risso) -Taddei Ruggiero, p. 211, pl.3, figs 1-2.

2004 Argyrotheca cordata (Risso, 1826) -Bitner and Kaim, p. 197, Tab. 2, figs 2D-K, 3A-E.

Morphology. Two complete and a lot of fragmented specimens. It is small, thin-shelled, subtriangular in outline, smooth covered with almost imperceptible ribs. The anterior commissure is slightly sulcate with a shallow sulcus present in both valves. The sizes of the shell reach the 2 $\mathrm{mm}$ in length and $2 \mathrm{~mm}$ in width.

Occurrence. As a fossil A. cordata is known from the Miocene throughout Europe and from the Pliocene of Italy and Spain. Today it is living in the Mediterranean Sea and the Mauritanian region 
of the Atlantic Ocean (see Bitner 1990). It is living in the infra-circallitoral zone no deeper than $100 \mathrm{~m}$ and belongs to the "shallow water" group of brachiopods in the Mediterranean sea (Logan 1979). Asgaard and Bromley (1991) confirm the cryptic mode of life of $A$. cordata in shallow water.

\author{
SUBPHYLUM CRANIFORMEA \\ CLASS CRANIATA \\ ORDER CRANIIDA Waagen, 1885 \\ SUBORDER CRANIIDINA Waagen, 1885 \\ Superfamily CRANIOIDEA Menke, 1828 \\ Family Craniidae Menke, 1828 \\ Genus Novocrania Lee and Brunton, 2001 \\ Novocrania anomala (Müller, 1776)
}

(Plate 1, Figs 7-8)

\begin{abstract}
1888 Crania turbinata (Poli) -Davidson, p. 188, pl. 27, figs. 14-23
1981 Crania anomala turbinata (Poli) -Cooper, p. 211, pl. 1, fig. 26

1986 Neocrania anomala (Muller) -Lee and Brunton, p. 150, figs 32-37.

2001 Novocrania anomala (Muller) -Lee and Brunton, p. 5
\end{abstract}

Morphology. Only the dorsal valve is available for examination. It is roundly elliptical, with conical profile, smooth, exterior ornamented only by concentric growth lines. Its shape is often determined by the shape of its host. The collected specimens are about $4 \mathrm{~mm}$ in length and $4.9 \mathrm{~mm}$ in width.

Occurrence. N. anomala is recorded from the Middle Miocene of Poland (Popiel-Barczyk and Barczyk 1990), the Pliocene and Pleistocene of Italy (Taddei Ruggiero, 1994) and is still living. It is epifaunal attached to hard substrates, living from the low tide limit in low intensity light (caves), to the bathyal zone.

Today in the Mediterranean it lives at depths from 3 to more than $300 \mathrm{~m}$. It is associated with Gryphus vitreus on hard substrates at depths of $120 \mathrm{~m}$ to more than $1000 \mathrm{~m}$ (Logan 1979, Logan et al. 2004).

\title{
3.2. Paleoecology
}

The distribution of brachiopods depends on many factors as the type of substrate, hydrodynamics, temperature and salinity (Emig 1988). They should thus be used with caution as palaeobathymetric indicators (Fisher and Oehlert 1891, Logan 1993).

Steinthorsdottir et al. (2006), have given the paleobathymetry of Kolymbia limestone deposits according to which "the limestone comprises two parasequences in a transgressive systems tract and deposition occurred at paleodepths between 30 and $120 \mathrm{~m}$ ".

These paleobathymetric data are reinforced by the study of the brachiopod and other faunas in each coarser horizon:

The dominance of Ostrea lamellosa in the sample 1 at the bottom of the section, indicates an environment of the littoral zone, rich in oxygen and with high turbulence, as this species is attached and generally forms asymmetrical banks in this zone (Pouyet 1984, Ben Moussa 1994). The simultaneous presence of the micromorph brachiopod fauna of Argyrotheca cordata, Megerlia truncata, along with the presence of Megathiris detruncata, indicates a very shallowwater and high energy environment (Laurain 1984, Asgaard and Bromley 1991).

In sample 2 the presence of Celleporaria palmata points to a depth of 30-50 m (Spjeldnaes and Moissette 1997, Steinthorsdottir et al. 2006). In this bed Gryphus sp. and Megerlia truncata var. monstruosa, have been found in situ, with transported rhodoliths. 
Plate 1 - Figs 1, 2, 3, 4. -Gryphus sp. posterior, posterior, lateral and latero-dorsal views. Figs 5, 6. -Terebratulina retusa (Linnaeus) dorsal and ventral views.

Figs 7, 8. -Megerlia truncata (Linnaeus) dorsal and ventral views

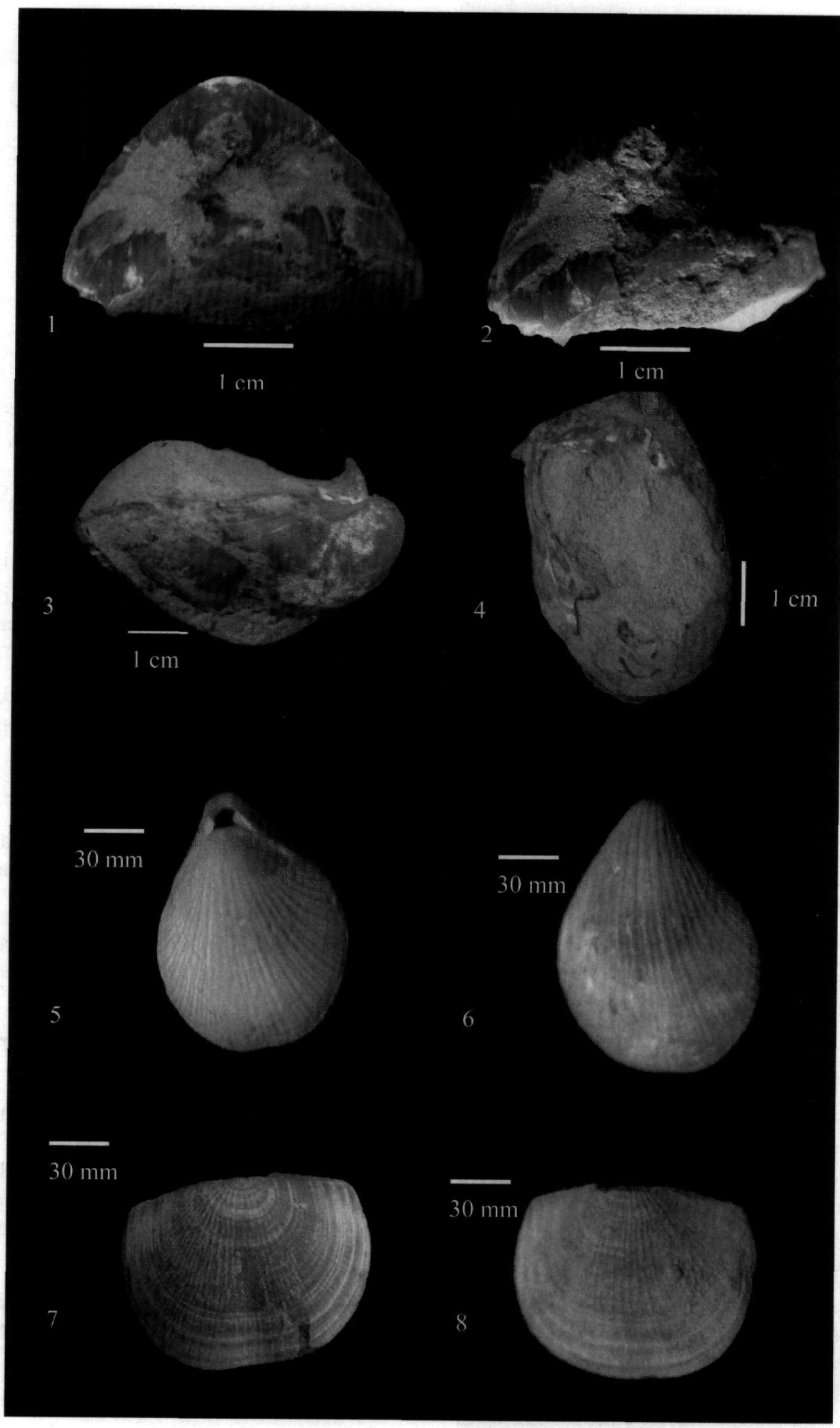


In samples 3 and 4 the association of Gryphus sp., Terebratulina retusa and Novocrania anomala points to a depth of more than 120 m of moderate energy (Logan 1979, Logan et al. 2004, Emig $1989 \mathrm{a}, \mathrm{b}$ ). Sample 4 according to Steinthorsdottir et al. (2006) represents a tectonic or storm event where fauna mixing dominates and Gryphus is coming from deeper water.

Sample 5 resembles sample 2 by its the fauna content.

\section{Conclusions}

The Pliocene brachiopod assemblages identified in this study have similar composition to some Recent assemblages of the Mediterranean Sea.

For the first time Megerlia truncata var. monstruosa, is recorded from the Pliocene of Greece and Megerlia truncata from the Pliocene of Rhodes. Megathiris detruncata, Terebratulina retusa and Argyrotheca cordata have been first described from the Pliocene of Rhodes. Also the species Novocrania anomala and Gryphus sp. are described and Gryphus vitreus of Steinthorsdottir et al. (2006) is discussed to be revised.

The three micromorph species of brachiopods Argyrotheca cordata, Megerlia truncata and Megathiris detruncata, are present in the assemblage of the sandy, lower part of the Cape Vagia section. This indicates a shallow-water and high-energy littoral environment.

In accordance with previous sedimentological and paleoecological studies based on bryozoans (Spjeldnaes and Moissette 1997, Steinthorsdottir et al. 2006), the associations of Gryphus sp. and Megerlia truncata var. monstruosa, and of Gryphus sp., Terebratulina retusa and Novocrania anomala, are interpreted as indicating depths of 30-50 and more than $120 \mathrm{~m}$ respectively.

\section{Acknowledgements}

The author is grateful to Pierre Moissette (University of Lyon 1) for his collaboration during field work. The critical comments and useful suggestions made by Aleksandra Bitner and Pierre Moissette and the help provided by Daphne Lee, were greatly appreciated. Thanks are due to Dimitri Velitzelos for his help with the macrophotographs and the technician Evangelos Michailides for his help during SEM observations. Financial support for this study was provided by Research Project 70/4/5849 of the University of Athens.

\section{References}

Asgaard, U., and Bromley, R.G., 1991. Colonization by micromorph brachiopods in the shallow subtidal of the Eastern Mediterranean Sea. In D.I. MacKinnon, D.E. Lee and J.D. Campell (eds). Brachiopods through time, 261-269, Proc. $2^{\text {nd }}$ Int. Brachiopods Congr. University of Otago, New Zealand, 5-9 February, 1990.

Benda, L., Meulenkamp, J.E., and van de Weerd, A., 1977. Biostratigraphic correlations in the Eastern Mediterranean Neogene. 3. Correlation between mammal, sporomorph and marine microfossil assemblages from the Upper Cenozoic of Rhodos, Greece, Newsletters on Stratigraphy, 6, 117-130.

Ben Moussa, A., 1994. Les bivalves Néogènes du Maroc septentrional (façades Atlantique et Méditerranéenne). Biostratigraphie, paléobiogéographie et paléoécologie, Docum. Lab. Géol. Lyon, 132, 281.

Bitner, M.A., 1990. Middle Miocene (Badenian) brachiopods from the Roztocze Hills, south-eastern Poland, Acta Geologica Polonica, 40, 139-157.

Bitner, M. A., and Martinell, J. 2001. Pliocene brachiopods from the Estepona Area (Malaga, South Spain), Revista Espapola de Paleontologia, 16, 177-185. 
Plate 2 - Figs 1, 2. -Megerlia truncata var. monstruosa ventral and dorsal views. Figs 3, 4. -Megathiris detruncata (Gmelin) ventral and dorsal views.

Figs 5, 6. - Argyrotheca cordata (Risso) dorsal and ventral views.

Figs 7, 8. -Novocrania anomala (Müller) outerl and inner of the dorsal valve.

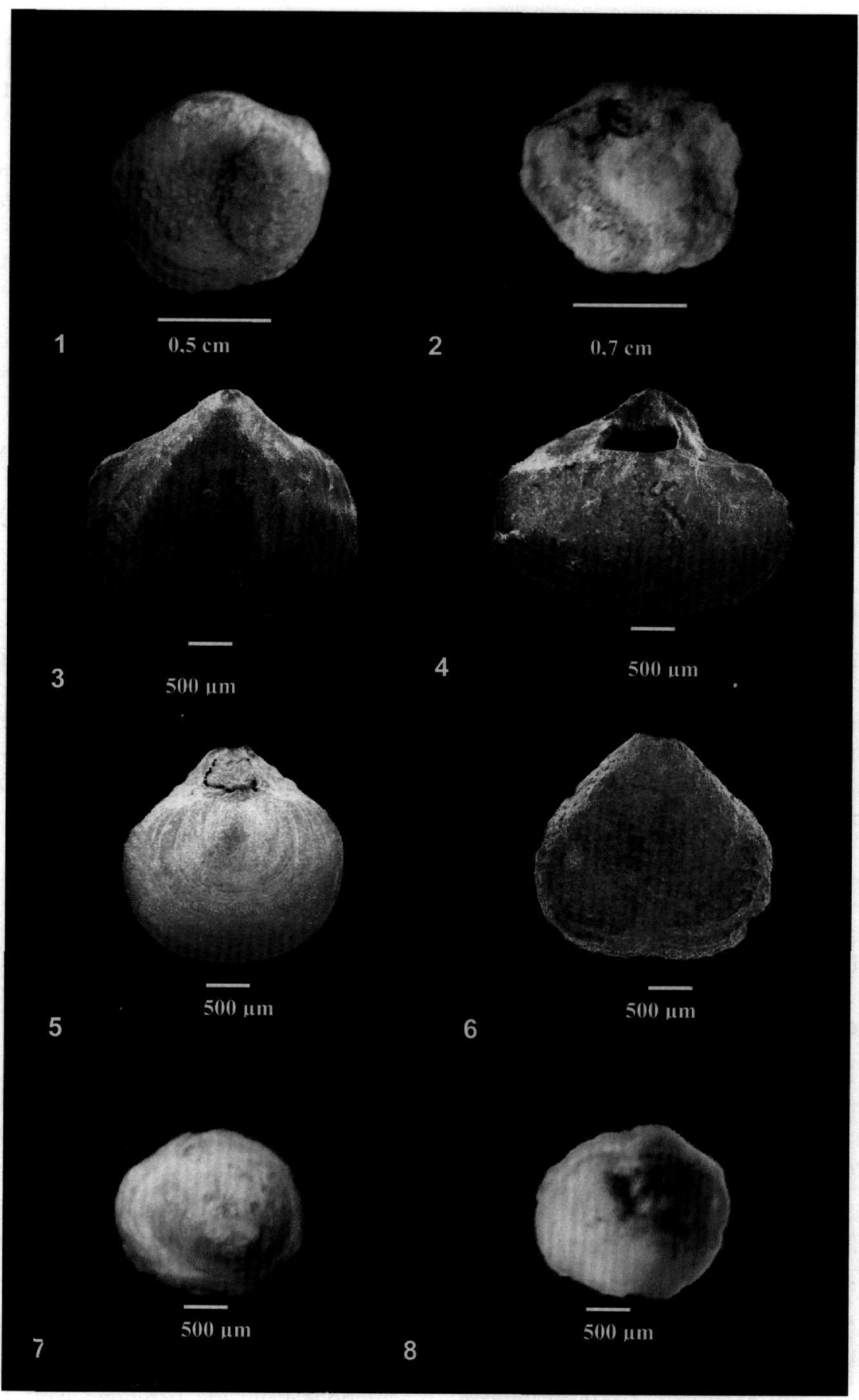


Bitner, M. A., and Moissette, P., 2003. Pliocene brachiopods from north-western Africa, Geodiversitas, 25 (3), 463-479.

Bitner, M. A., and Kaim, A., 2004. The Miocene brachiopods from the silty facies of the intraCarpathian Nowy Sącz Basin (Poland), Geological Quarterly, 48 (2), 193-198.

Bukowski, G. V., 1899. Geologische Uebersichtkarte der insel Rhodus, Jahrb. K. K. Geol. Reichsanst., 4, 517-688.

Cooper, G. A., 1977. Brachiopods from the Caribbean Sea and adjacent waters, Studies in Tropical Oceanography, 14, 1-211.

Cooper, G.A., 1981. Brachiopoda from the Gulf of Gascogne, France (Recent). Smithson. Contrib. Paleobiol., 44, i-iv, 1-35.

Cornée, J.J., Moissette, P., Joannin, S., Suc, J.P., Quillévéré, F., Krijgsman, W., Hilgen, E., Koskeridou, E., Münch, P., Lécuyer, C., and Desvignes, P., 2006. Tectonic and climatic controls on coastal sedimentation: the Late Pliocene-Middle Pleistocene of northeastern Rhodes Greece, Sedimentary Geology, 187, 159-181.

Cornée, J.J., Münch, P., Quillévéré, F., Moissette, P., Vasiliev, I., Krijgsman, W., Verati, C., and Lécuyer, C., 2006b. Timing of Late Pliocene to Middle Pleistocene tectonic events in Rhodes (Greece) inferred from magneto-biostratigraphy and ${ }^{40} \mathrm{Ar} /{ }^{39} \mathrm{Ar}$ dating of a volcaniclastic layer, Earth and Planetary Science Letters, 250, 281-291.

Davidson, T., 1886-1888. A monograph of Recent Brachiopoda, Linnean Soc. London, Trans., ser. $2,4,1-248$.

Dermitzakis, M., 1969. Geological researches on the Neogene of Ierapetra province of Crete island, Annales Géologiques des Pays Helléniques, 1, XXI, 342pp.

Emig, C.C., 1988. Les Brachiopodes actuels sont-ils des indicateurs (paleo) bathymétriques? Géologie méditerranéenne, 15(1), 65-71.

Emig, C.C., 1989a. Distribution bathymétrique et spatiale des populations de Gryphus vitreus (brachiopode) sur la marge continentale (Nord-Ouest Méditerranée), Oceanol. Acta, 12, 205-209.

Emig, C.C., 1989b. Distributional patterns along the Mediterranean continental margin (upper bathyal) using Gryphus vitreus (Brachiopoda) densities, Palaegeography, Palaeoclimatology, Palaeoecology, 71, 253-256

Fisher, P., and Oehlert, D. P., 1891. Brachiopodes. Expéditions scientifiques du « Travailleur » et $d u$ « Talisman » pendant les années 1880, 1881, 1882, 1883. Masson, Paris, 140pp.

Gaetani, M., and Sacca, D., 1984. Brachiopodi batiali nel Pliocene e Pleistocene di Sicilia e Calabria, Rivista Italiana di Paleontologia e Stratigrafia, 90, 407-458.

Gaetani, M., and Sacca, D., 1985. Brachiopodi neogenici e pleistocenici della provincia di Messina e della Calabria meridionale, Geologica Romana, 22 (1983), 1-43.

Georgiades-Dikeoulia, E., 1974. Les Brachiopodes du Miocène moyen de l' ile de Crete (Hangii Assomati, Rethymnos), Annales Géologiques des Pays Helléniques, 26, 159-185.

Gmelin, J.F., 1790. Systema naturae, sive Regna tria Naturae systematice proposita per classes, ordines, genera et species, Regnum animale, 13 ed., Stockholm, 3021-3910.

Hanken, N. M., Bromley, R.G., and Miller, J., 1996. Plic-Pleistocene sedimentation in coastal grabens, north-east Rhodes, Greece, Geological Journal, 31, 271-296.

Hedenborg, J., 1837. (On the Tertiary formations on the Island of Rhodes): Skandia, 10, 238-260. 
Keraudren, B., 1970. Les formations quaternaires marines de la Grèce, Bulletin du Musée d'Anthropologie Préhistorique de Monaco, 6, 5-153.

Laurain, M., (1984) Bivalves Ostréidés. In: Pouyet S (ed) La faune du faciès "Marnes Bleues", Burdigalien du bassin de Faucon-Mollans-Malaucène (sud-est de la France), Nouv. Arch. Mus. d'Hist. Nat. Lyon, 22, 74-78.

Lee, D.E., and Brunton, C.H.C., 1986. Neocrania n. gen., and a revision of Cretaceous-Recent brachiopod genera in the family Craniidae, Bull. Br. Mus. Nat. Hist. (Geol.), 40 (4), 141160.

Lee, D.E., and Brunton, C.H.C., 2001. Novocrania, a new name for the genus Neocrania Lee and Brunton, 1986 (Brachiopoda, Craniida), preoccupied by Neocrania Davis, 1978 (Insecta, Lepidoptera), Bulletin of the Natural History Museum (Geology Series), 57(1), 5.

Linnaeus, C., 1758-1767. Systema Naturae, 10th ed., Holmiae, 823 pp.

Logan, A., 1979. The Recent Brachiopoda of the Mediterranean Sea, Bulletin de l'Institut océanographique de Monaco, 72, 1-112.

Logan, A., 1983. Brachiopoda collected by CANCAP I-III expeditions to the south-east North Atlantic. 1976-1978, Zoologische Mededelingen Leiden, 57, 165-189.

Logan, A., 1988. Brachiopoda collected by CANCAP IV and VI expeditions to the south-east North Atlantic. 1980-1982. Zoologische Mededelingen Leiden, 62, 59-74.

Logan, A., 1993. Recent brachiopods from the Canarian-Cape Verdean region: Diversity, biogeographic affinities, bathymetric range and life habits, Courier Forschungsinstitut Senckenberg, 159, 229-233.

Logan, A., Bianchi, C.N., Morri, C., and Zibrowius, H., 2004. The present-day Mediterranean brachiopod fauna: diversity, life habits, biogeography and paleobiogeography, Scientia Marina, 68 (1), 163-170.

Løvlie, R., Støle, G., and Spjeldnaes, N., 1989. Magnetic polarity stratigraphy of PliocenePleistocene marine sediments from Rhodos, eastern Mediterranean, Physics of the Earth and Planetary Interiors, 54, 340-352.

Meulenkamp, J.E., De Mulder, E.F.J., and Van De Weerd, A., 1972. Sedimentary history and paleogeography of the Late Cenozoic of the Island of Rhodos, Zeitschrift der Deutschen Geologischen Gesellschaft, 123, 541-553.

Moissette, P., and Spjeldnaes, N., 1995. Plio-Pleistocene deep-water bryozoans from Rhodes, Greece, Palaeontology, 38, 771-799.

Moissette, P., Koskeridou, E., Cornée, J.J., Guillocheau, F., and Lécuyer, C., in press. Spectacular preservation of seagrasses and seagrass-associated communities from the Pliocene of Rhodes, Greece, Palaios.

Mutti, E., Orombelli, G., and Pozzi, R., 1970a. Geological map of Rhodes Island (Greece), Annales Géologiques des Pays Helléniques, 22.

Mutti, E., Orombelli, G., and Pozzi, R., 1970b. Geological studies on the Dodecanese Islands (Aegean Sea). IX. Geological map of the island of Rhodes (Greece); explanatory notes., Annales Géologiques des Pays Helléniques, 22, 79-226.

Pirazzoli, P.A., Montaggioni, L.F., Thommeret, J., Thommeret, Y., and Laborel, J., 1983. Sur les lignes de rivage et la neotectonique a Rhodes (Grece) a l'Holocene, Ann. Inst. Océanogr., $58,89-102$. 
Pirazzoli, P.A., Montaggioni, L.F., Saliege, J.F., Segonzac, G., Thommeret, Y., and VergnaudGrazzini, C., 1989. Crustal block movements from Holocene shorelines: Rhodes Island (Greece), Tectonophysics, 170, 89-114.

Popiel-Barczyk, E., and Barczyk, W., 1990. Middle Miocene (Badenian) brachiopods from the southern slopes of the Holy Cross Mountains, Central Poland, Acta Geol. Pol., 40 (3-4), 159-181.

Pouyet, S., 1984. La faune du faciès "Marnes bleues". Burdigalien du bassin de Faucon-MollansMalaucène (Sud-Est de la France), Nouvelles Archives du Museum d'Histoire Naturelle de Lyon, 22, 51-123.

Sissingh, W., 1972. Late Cenozoic Ostracoda of the South Aegean Island Arc, Utrecht Micropaleontological Bulletins, 6, 1-187.

Spanopoulou, A., 1997. The Plio-Pleistocene Brachiopods of Rhodes island, Unpublished Master thesis, University of Athens. $287 \mathrm{pp}$.

Spjeldnaes, N., and Moissette, P., 1997. Celleporid (bryozoan) thickets from the Upper Pliocene of the island of Rhodes, Greece. In N.P. James and J.A.D. Clarke (eds), Cool-Water Carbonates, SEPM Spec. Publ., 56, 263-270pp.

Steinthorsdottir, M., Lidgard, S., and Hakansson, E., 2006. Fossils, sediments, tectonics. Reconstructing palaeoenvironments in a Pliocene-Pleistocene Mediterranean microbasin, Facies, 52, 361-380.

Symeonides, N., 1966. The Neogene of eastern Crete, Annales Géologiques des Pays Helléniques, 1, XVI, 249 pp.

Taddei-Ruggiero, E., 1994. Neogene Salento brachiopod palaeocommunities, Bollettino della Societa Paleontologica Italiana, 33, 197-213.

Thomsen, E., Rasmussen, T.L., and Hastrup, A., 2001. Calcareous nannofossil, ostracode and foraminifera biostratigraphy of Plio-Pleistocene deposits, Rhodes (Greece), with a correlation to the Vrica section (Italy), Journal of Micropalaeontology, 20, 143-154.

Thomson, J.A., 1927. Brachiopod morphology and genera (Recent and Tertiary), New Zealand Board Science and Art, Manual, 7, 338 pp.

Williams, A., Carlson, S. J., Brunton, C. H. C., Holmer, L. E., and Popov, L. 1996. A supraordinal classification of the Brachiopoda. Philosophical Transactions of the Royal Society of London, B, 351, 171-1193.

Zezina, O.N., 1985. Living brachiopods and problems of the bathyal zone in the oceans, Akademiia Nauk. SSSR, 247 pp. 